\title{
Indonesian Sign Language Interpreter Device Based on ATMega328 Microcontroller for Bali Deaf Community Denpasar
}

\author{
I Wayan Sukadana ${ }^{1 *}$ \\ ${ }^{1}$ Electrical Engineering Study Program, Faculty of Engineering and Informatics \\ Universitas Pendidikan Nasional, Denpasar, Indonesia \\ sukadana@undiknas.ac.id \\ I Nengah Agus Mulia Adnyana ${ }^{2}$, Erwani Merry Sartika ${ }^{3}$ \\ ${ }^{2}$ Electrical Engineering Study Program, Faculty of Engineering and Informatics \\ Universitas Pendidikan Nasional, Denpasar, Indonesia \\ ${ }^{3}$ Bachelor Program in Electrical Engineering, Faculty of Engineering \\ Universitas Kristen Maranatha, Bandung, Indonesia \\ agusmuliadnyana@yahoo.co.id,erwani.ms@eng.maranatha.edu
}

(Received April 07, 2021, accepted April 29, 2021)

\begin{abstract}
This study aims to design and build a Sign Language Interpreter Device with Voice Output in the form of an ATMega328 Microcontroller-Based Voice Speaker Module so that in its implementation and later in designing this device the writer focuses on the translation of 16 words that have been predetermined in Indonesian Sign Language especially in Denpasar City by using a Flex Sensor and a Gyro Sensor based on the ATMega328 Microcontroller with Arduino IDE programming. This device is also equipped with a $4 G B S D$ card memory for storing voice recordings, using an ATMega328 microcontroller, four analog Flex sensors, a Gyro sensor, a buzzer and an $8 \mathrm{ohm}$ speaker, and using a 7.4 volt Li-Po battery. The application of this device is aimed for thehearing impaired people who fall into the adult category who can understand writing and understand sign language. The output of this device uses an MP3 player module that is already included in the Sign Language Interpreter Device. The flex sensor readings range from 998-1005 ADC (analog digital converter) in open conditions and the sensor ranges from 1006-10018 ADC in closed conditions. The reading for the gyro pitch ( $Y$ axis) ranges from $-10^{\circ}$ to $76^{\circ}$ then on the reading of the gyro Roll (X axis) ranges from $-100^{\circ}$ to $90^{\circ}$.
\end{abstract}

Keywords: ATMega328 microcontroller; Buzzer; Flex Sensor; Gyro Sensor 


\section{Introduction}

Indonesia is a country with various ethnic groups, religions and languages. This diversity is interwoven in the bonds of one nation of Indonesia as a whole and sovereign nation. The Indonesian nation is based on the unity of views, ideology and philosophy of life in the nation and state which are reflected in the Pancasila principles which are the basis of the Indonesian country and are written in the state symbol which reads "Bhinneka Tunggal Ika", which means "diverse" (ethnic groups, religions, languages) (Yohanes et al., 2013).

For the people who can hear or so called with the term "hearing community", oral language is the main means of carrying out the process of direct interaction, but for the group of deaf people it will be ineffective. The deaf community group is a group of people with special needs who have hearing disorders with mild, moderate and serious disorder limits. The deaf community can still communicate between them and also with the "hearing community" by using a language commonly known as sign language (Gumelar et al., 2018).

Sign language is a language that is conveyed visually to communicate. In linguistics, sign language is recognized as a complete language. Because it is a natural language, sign language has its own grammar like any other spoken language. Sign language also has unique features that spoken language does not have. For example, in Bahasa Denpasar Regional Sign Language, numbers are placed after nomina or nouns as in PENCIL-TWO, "two pencils" (Effendi, 2018).

Article 42 BISINDO in UU Nomor 8 Tahun 2016 (Law Number 8 Year 2016) concerning persons with disabilities, Bisindo is a sign language that appears naturally in Indonesian culture and is practical to be used in everyday life so that BISINDO has several variations in each region. Meanwhile, SIBI is a signaling system that is recognized by the government and is used in teaching in special schools for the hearing impaired people (SLB/B) (Kepmendikbud, 1994). BISINDO, which has been used daily by the Deaf community, contains a symbolic sign vocabulary. As long as the meaning of a word is represented, BISINDO's simple sign vocabulary is sufficient. Meanwhile, SIBI was created to teach the Indonesian language system to special school children. The rules for using sign language in SIBI are more complicated and leveled (Ade et al., 2019). 
One of the developed sign language in the city of Denpasar is Indonesian Sign Language (BISINDO) Denpasar Region. Denpasar is one of the areas often used by the Deaf Community to introduce the Indonesian Sign Language (BISINDO) of the Denpasar region to the wider community. The development that has been carried out by the Deaf Community has made the use of Indonesian Sign Language (BISINDO) of Denpasar Region not only for the Deaf Community, but also for the "hearing community" (Yohanes et al., 2013).

A sign language interpreter is a person (both normal and hearing impaired people) who have the ability to interpret sign language directly, precisely and accurately, who have received a sign language interpreter education from an organization recognized by the local Deaf community. The development of the use of Indonesian Sign Language (BISINDO) of Denpasar Region has become interesting for designing device that can change or convert sign language into output in the form of an audio speaker module using a flex sensor and a gyro sensor based on the ATMega328 microcontroller with Arduino IDE programming.(Kadir, 2013) (Zulfikar, 2018). This device only translates Indonesian Sign Language (BISINDO) of Denpasar Region. For that reason, a community service program was carried out in the form of "INDONESIAN SIGN LANGUAGE INTERPRETER DEVICE BASED ON ATMEGA328 MICROCONTROLLER FOR BALI DEAF COMMUNITY DENPASAR".

\section{Methods}

There are several methods used in the activity of designing an Indonesian sign language interpreter device based on the ATMega328 microcontroller for Bali Deaf Community Denpasar, among others, by carrying out data collection techniques both primary and secondary data.

\section{Primary Data Collection Method}

Primary data is a source of data obtained from the original source directly and not through intermediaries. Primary data collection methods used are by conducting interviews and observations.

1. Interviews

The interview method was used to get as much information as possible about the system that was going to be made to assist in carrying out activities in the Bali Deaf Community. 
Interviews were conducted with Gede Ade Putra Wirawan as the founder, chairman and representative of the Bali Deaf Community, who stated that the sign language interpreter device is very effective and useful for helping to introduce sign language for the "hearing community" so that it is easier to understand and can attract interest in learning sign language.

\section{Observations}

This is direct observation in the Deaf Community by observing the interaction using Indonesian Sign Language (BISINDO) of Denpasar Region between the Deaf community and the "hearing community" to determine 3 sentences to be used in the design of the interpreter device.

\section{Secondary Data Collection Method}

Secondary data collection was carried out through theoretical studies both by reading literature in libraries and scientific journals related to this activity. The results obtained from this method include:

1. Sign language has its own grammar rules with sentence patterns in Indonesian Sign Language (BISINDO) of Denpasar Region is Subject-Object-Verb or Subject-ObjectVerb-Subject.

2. Arduino Uno provides $13 \mathrm{I} / \mathrm{O}$ pins, consisting of 6 analog input pins and 14 digital I/O pins, and has a flash memory of $32 \mathrm{~KB}$ with $0.5 \mathrm{~KB}$ used as the bootloader.

3. The Flex Sensor is 4.5 inches in length where the resistance of this flexible sensor changes when the metal bearing is outside the bending. With specifications of temperature range: $-35^{\circ} \mathrm{C}$ to $+80^{\circ} \mathrm{C}$, flat resistance: $10 \mathrm{~K} \mathrm{Ohm}$, resistance tolerance: $\pm 30 \%$, bending resistance range: $60 \mathrm{~K} \mathrm{Ohm}$.

4. Gyro sensors have the ability that said to be accurate because there is hardware that works to convert analog data to digital form which has a 16-bit resolution on each channel.

System requirements analysis was carried out to identify the requirements needed in building a new system and evaluating existing problems. System requirements include:

1. Flex sensor as input to detect finger motion

2. Gyro sensor as wrist motion detection input

3. Using the ATMega328 microcontroller as a data processing center

4. Using buzzer as sound indicator that the system works

5. Audio Speaker module as output 
6. Glove as a placeholder for all components

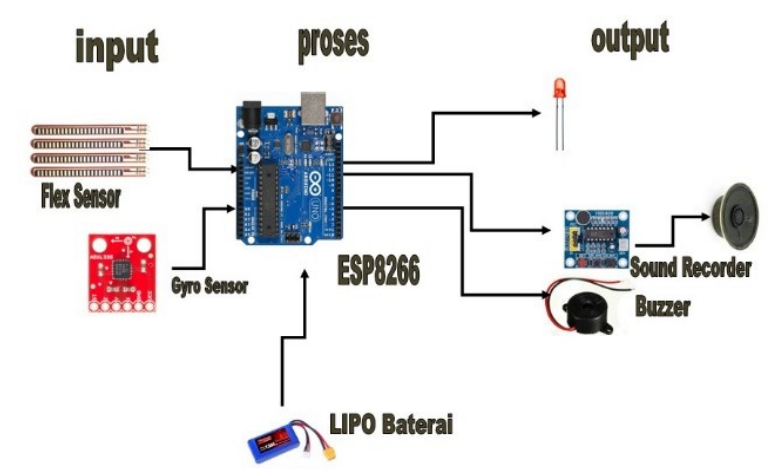

Fig. 1. Block diagram of sign language interpreter device system design

Figure 1 is a block diagram of the microcontroller-based Indonesian sign language interpreter system design. This design consists of several components, namely the Arduino Uno microcontroller, Flex Sensor, Gyro Sensor, DC Regulator, 7.4 volt Li-Po Battery, Sound Recorder, Buzzer, and a Laptop which was only used when programming the device for the first time. The 7.4 volt Li-Po battery will provide voltage to the Arduino Uno microcontroller. If everything is connected, the sign language interpreter device will be active, indicated by a sound from the buzzer, and when the sensor has calibrated the device is ready to work.

Broadly speaking, the design of the sign language interpreter device with voice output to speaker module based on the ATMega328 microcontroller consists of two parts, namely hardware and software. The software is in the form of an Arduino IDE program to be uploaded into the microcontroller system. To make it easier to design a working system, a system flowchart was created first which can be seen in Figure 2.

In making the design of the sign language interpreter device, it was necessary to have a test that aims to determine whether the prototype device was working or not. Then scenarios were tested, those were:

a. The first test scenario was that the user tries to convey Sign Language 1 that has been stored in the Sign Language Interpreter Device then pay attention and listen and record the results.

b. The second test scenario was that the user tries to convey Sign Language 2 which was already stored in the Sign Language Interpreter Device then pay attention and listen and record the results. 
c. The third test scenario was that the user tries to convey Sign Language 3 that has been stored in the Sign Language Interpreter Device then pay attention and listen and record the results.

d. The fourth test scenario was that the user tries to convey the finish Sign Language that has been stored in the Sign Language Interpreter Device then pay attention and listen and record the results.

e. The fifth test scenario was that the user tries to convey Sign Language that was not stored on the Sign Language Interpreter Device then pay attention and listen and record the results.

The results of the system design starting from the installation of components and system configuration, programming, to system testing and implementation of the Sign Language Interpreter Device with voice output are in the following.

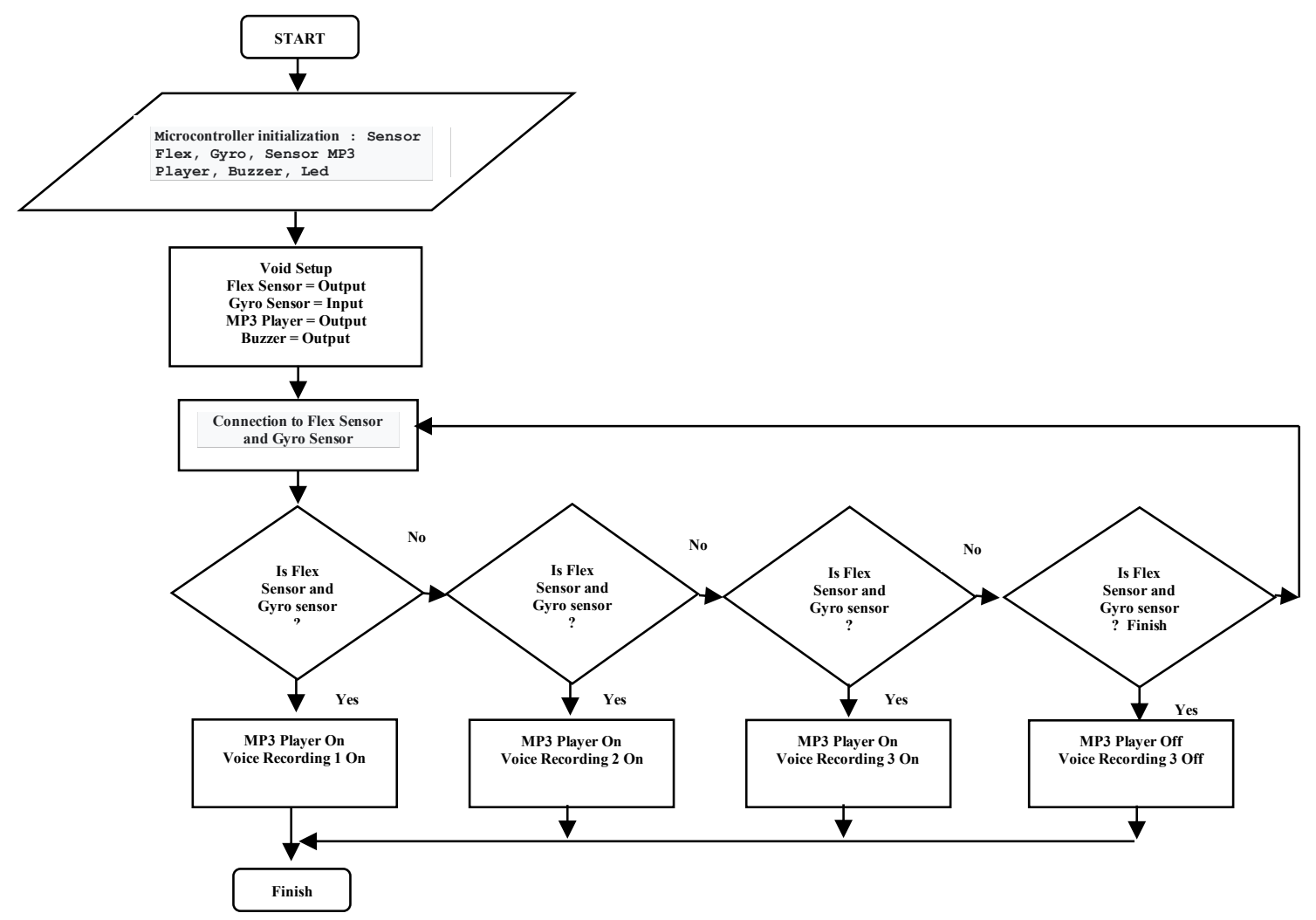

Fig. 2. Flow chart of sign language interpreter device system design

\section{Design of the Sign Language Interpreter Device System}

In the first stage, the design of the Sign Language Interpreter Device with sound output was the manufacture of a component holder box with a length of $14.5 \mathrm{~cm}$, a width of $9.5 \mathrm{~cm}$ and a height of $5.5 \mathrm{~cm}$ made of plastic with a thickness of $3 \mathrm{~mm}$ as shown in Figure 3. Meanwhile, 
the process of making a point for placing the components and locking bolts on the gloves is shown in Figure 4.

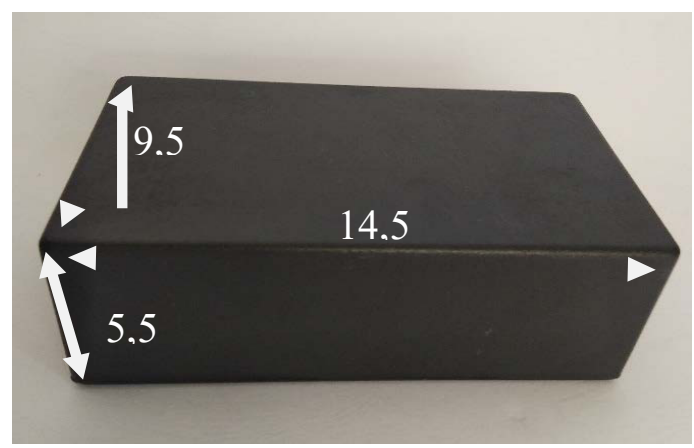

Fig. 3. Components box

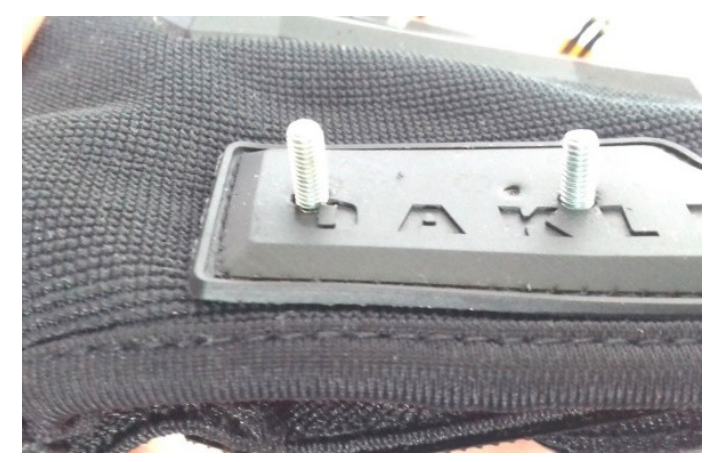

Fig. 4. Components placeholder

After making the placeholder for the components in the box, following next was the installation stage of 4 flex sensors and the MPU6050 type gyro sensor, those were attached to the glove using a glue gun as shown in Figure 5 and Figure 6 . Then followed by the installation process of the Li-Po 7.4 volt/850mAh battery, and the $8 \mathrm{Ohm}$ audio speaker in the inside of the box as shown in Figure 7 and Figure 8.

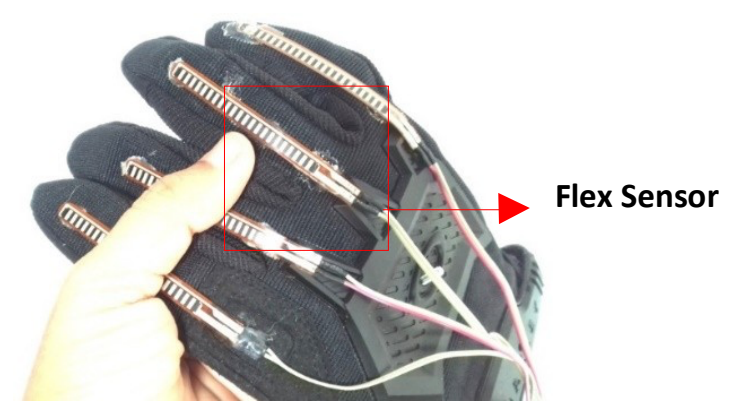

Fig. 5. Installation of 4 flex sensors

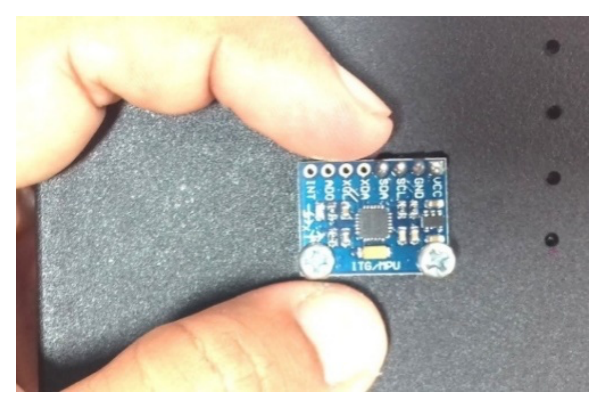

Fig. 6. Installation ofgyro sensor 


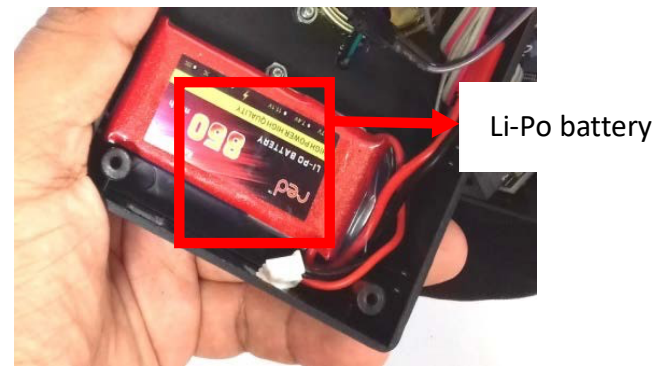

Fig 7. Battery installation

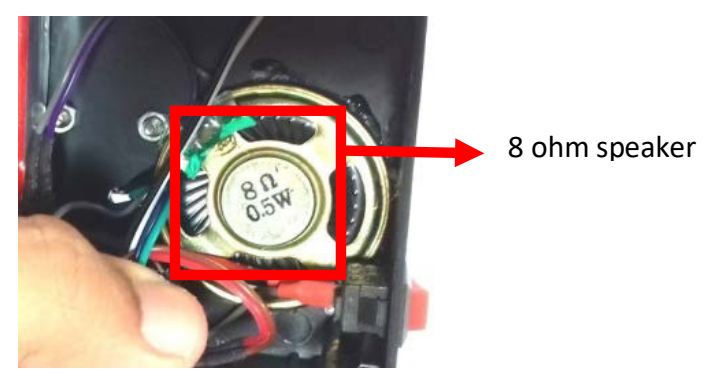

Fig. 8. Audio speaker installation

Next was the process of installing the ATMega328 microcontroller board which was in the inner of the component box and installing the MP3 player board which was connected to the ATMega328 board using digital pins 3 and 4 as shown in Figure 9 and Figure 10.

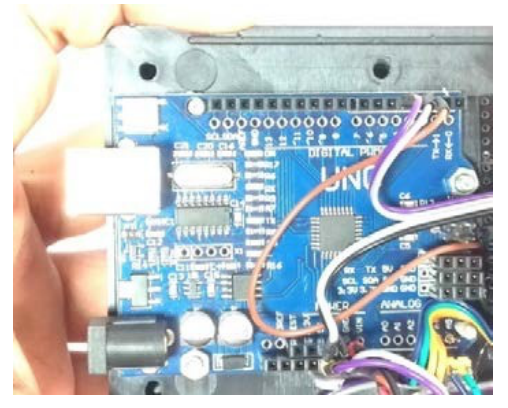

Fig. 9. ATMega328 board installation

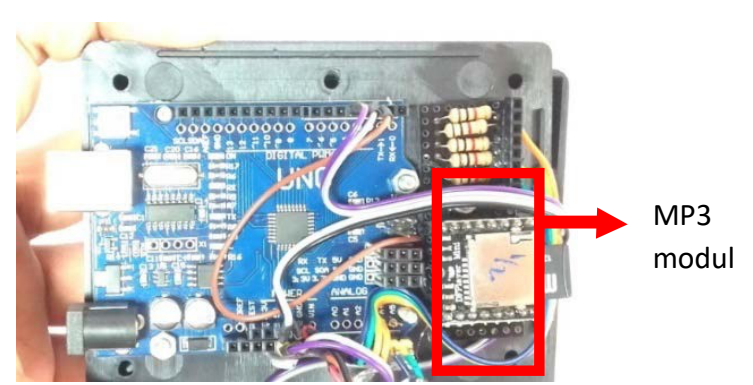

Fig. 10. MP3 player board installation

The final installation process was the process of installing nuts and bolts from pre-assembled components, installing the complete component box to the bottom cover and component box along with gloves that have been installed with a flex sensor as shown in Figure 11 and Figure 12.

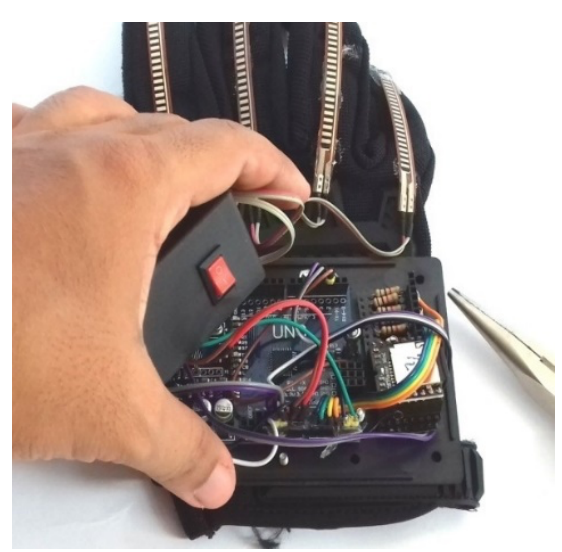

Fig. 11. All components assembly

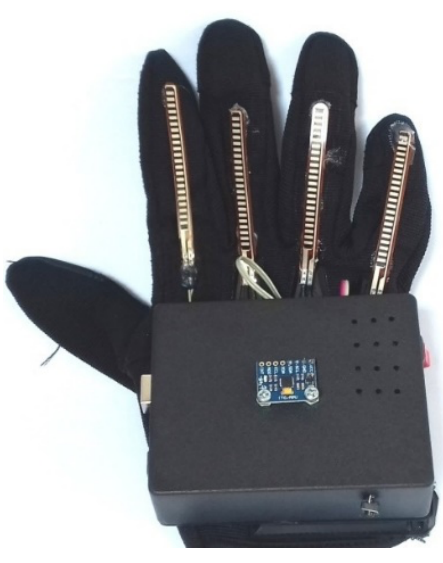

Fig. 12. Final product of the system 
Programming using the Arduino IDE began with the process of initializing the MPU 6050 Gyro Sensor, MP3 player, Flex Sensor, buzzer and ATMega328. Next was the declaration process for all the variables used then setting the void setup of a sign language interpreter with sound output, setting the buzzer pin to output, setting the Gyro Sensor pin, activating the MP3 player module to turn on the sound recording at address 1, and setting the MP3 player module volume 30.

Flex sensor testing was carried out to determine the reading value of the flex sensor, read on the Arduino IDE serial monitor. This sensor reading was used to read the value according to determined hand movements signal. The first test was done by reading the value of the flex sensor in ADC (analog digital converter) units. From the flex sensor, the value was obtained if the flex sensor condition was straight, the ADC value output ranges from 990 to 995 , but if the flex sensor was bent, the value read on the Arduino IDE monitor series ranges from 1000 to 1025 depending on the size of the bending of the flex sensor, as shown in Figure 13 and Figure 14.

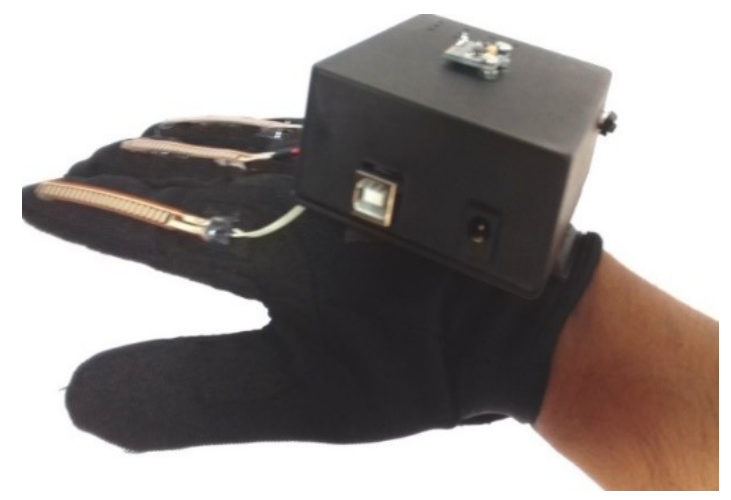

Fig. 13. Flex sensor test-opened

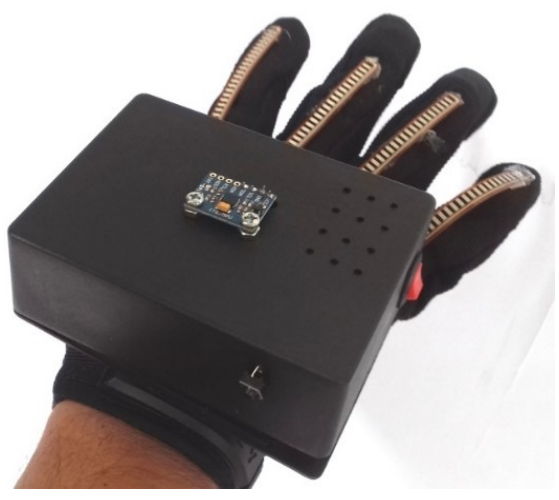

Fig. 14. Flex sensor test-closed

From the results of tests carried out 10 times with 2 types of reading movements, namely opened and closed with measurement of the ADC value of the flex sensor, the results can be shown in Table 1.

\section{Sensor Test Results of First Sentence Sign}

Testing of the flex sensor and the gyro sensor was carried out to determine the reading value of the flex sensor and the gyro sensor that was read on the Arduino IDE Serial Monitor.The reading of this sensor was used to read the value of the determined hand movement signal. The first sentence was "Hello, nama saya Agus, Jurusan Teknik Elektro Universitas 
PendidikanNasional." ("Hello, my name is Agus, Department of Electrical Engineering, Universitas Pendidikan Nasional)". The test results and readings of the first sentence can be seen in Table 2.

Table 1. Results of testing the flex sensor in opened and closed conditions

\begin{tabular}{|c|c|c|c|c|c|c|c|c|c|c|c|}
\hline $\begin{array}{l}\text { Test } \\
\text { no. }\end{array}$ & $\begin{array}{c}\text { ADC } \\
\text { flex } 1 \\
\text { value } \\
\text { readings }\end{array}$ & $\begin{array}{c}\text { ADC } \\
\text { flex } 2 \\
\text { value } \\
\text { readings }\end{array}$ & $\begin{array}{c}\text { ADC } \\
\text { flex } 3 \\
\text { value } \\
\text { readings }\end{array}$ & $\begin{array}{c}\text { ADC } \\
\text { flex } 4 \\
\text { value } \\
\text { readings }\end{array}$ & Note & $\begin{array}{l}\text { Test } \\
\text { no. }\end{array}$ & $\begin{array}{c}\text { ADC } \\
\text { flex } 1 \\
\text { value } \\
\text { readings }\end{array}$ & $\begin{array}{c}\text { ADC } \\
\text { flex } 2 \\
\text { value } \\
\text { readings }\end{array}$ & $\begin{array}{c}\text { ADC } \\
\text { flex } 3 \\
\text { value } \\
\text { readings }\end{array}$ & $\begin{array}{c}\text { ADC } \\
\text { flex } 4 \\
\text { value } \\
\text { readings }\end{array}$ & Note \\
\hline 1 & 995 & 995 & 995 & 995 & $\begin{array}{l}\text { Opened } \\
\text { condition }\end{array}$ & 1 & 1020 & 1023 & 1019 & 1020 & $\begin{array}{c}\text { Close } \\
\text { condition }\end{array}$ \\
\hline 2 & 996 & 996 & 994 & 994 & $\begin{array}{l}\text { Opened } \\
\text { condition }\end{array}$ & 2 & 1021 & 1021 & 1019 & 1021 & $\begin{array}{l}\text { Close } \\
\text { condition }\end{array}$ \\
\hline 3 & 994 & 996 & 994 & 996 & $\begin{array}{l}\text { Opened } \\
\text { condition }\end{array}$ & 3 & 1018 & 1020 & 1020 & 1018 & $\begin{array}{l}\text { Close } \\
\text { condition }\end{array}$ \\
\hline 4 & 996 & 997 & 996 & 997 & $\begin{array}{l}\text { Opened } \\
\text { condition }\end{array}$ & 4 & 1022 & 1021 & 1021 & 1022 & $\begin{array}{l}\text { Close } \\
\text { condition }\end{array}$ \\
\hline 5 & 997 & 996 & 996 & 996 & $\begin{array}{l}\text { Opened } \\
\text { condition }\end{array}$ & 5 & 1022 & 1018 & 1018 & 1018 & $\begin{array}{l}\text { Close } \\
\text { condition }\end{array}$ \\
\hline 6 & 996 & 999 & 995 & 999 & $\begin{array}{l}\text { Opened } \\
\text { condition }\end{array}$ & 6 & 1019 & 1023 & 1019 & 1023 & $\begin{array}{l}\text { Close } \\
\text { condition }\end{array}$ \\
\hline 7 & 999 & 996 & 996 & 997 & $\begin{array}{l}\text { Opened } \\
\text { condition }\end{array}$ & 7 & 1020 & 1018 & 1020 & 1021 & $\begin{array}{l}\text { Close } \\
\text { condition }\end{array}$ \\
\hline 8 & 995 & 996 & 996 & 996 & $\begin{array}{l}\text { Opened } \\
\text { condition }\end{array}$ & 8 & 1021 & 1023 & 1019 & 1018 & $\begin{array}{l}\text { Close } \\
\text { condition }\end{array}$ \\
\hline 9 & 996 & 999 & 999 & 999 & $\begin{array}{l}\text { Opened } \\
\text { condition }\end{array}$ & 9 & 1018 & 1021 & 1019 & 1023 & $\begin{array}{l}\text { Close } \\
\text { condition }\end{array}$ \\
\hline 10 & 994 & 995 & 996 & 995 & $\begin{array}{l}\text { Opened } \\
\text { condition }\end{array}$ & $\begin{array}{l}1 \\
0\end{array}$ & 1022 & 1021 & 1023 & 1021 & $\begin{array}{l}\text { Close } \\
\text { condition }\end{array}$ \\
\hline
\end{tabular}

Table 2. Test result of the first sentence

\begin{tabular}{|c|c|c|c|c|c|c|c|}
\hline \multirow[b]{2}{*}{$\begin{array}{c}\text { Sentence } \\
\text { part }\end{array}$} & \multicolumn{2}{|c|}{$\begin{array}{c}\text { GyroSensor } \\
\text { Readings }\end{array}$} & \multicolumn{4}{|c|}{ Flex Sensor Readings } & \multirow[b]{2}{*}{ Note } \\
\hline & $\begin{array}{l}\text { Pitch } \\
\text { Value }\end{array}$ & $\begin{array}{l}\text { Roll } \\
\text { Value }\end{array}$ & Flex 1 & Flex 2 & Flex 3 & Flex 4 & \\
\hline Hello & $>75$ & $>90$ & $<1000$ & $<1000$ & $<1000$ & $<1000$ & Succeed \\
\hline Nama & $>20$ & $>-50$ & $<1000$ & $<1000$ & $>1000$ & $>1000$ & Succeed \\
\hline Saya & $>35$ & $>-40$ & $<1000$ & $<1000$ & $<1000$ & $<1000$ & Succeed \\
\hline Agus & $>38$ & $>25$ & $<1000$ & $>1000$ & $>1000$ & $>1000$ & Succeed \\
\hline Jurusan & $>10$ & $>-50$ & $<1000$ & $>1000$ & $>1000$ & $<1000$ & Succeed \\
\hline Elektro & $>-10$ & $>-50$ & $<1000$ & $<1000$ & $<1000$ & $>1000$ & Succeed \\
\hline Universitas & $>75$ & $>-25$ & $<1000$ & $<1000$ & $>1000$ & $>1000$ & Succeed \\
\hline Pendidikan & $>45$ & $>20$ & $>1000$ & $>1000$ & $>1000$ & $>1000$ & Succeed \\
\hline Nasional & $>75$ & $>-35$ & $<1000$ & $<1000$ & $>1000$ & $>1000$ & Succeed \\
\hline
\end{tabular}




\section{Sensor Test Results of Second Sentence Sign}

Testing of the Flex Sensor and the Gyro Sensor was carried out to determine the reading value of the flex sensor and the gyro sensor that was read on the Arduino IDE Serial Monitor. The reading of this sensor was used to read the value of the determined hand movement signal. The second sentence was “Saya Masyarakat Dengar berusaha mewujudkan lingkungan ramah tuli, terimakasih." ("I am Hearing Society trying to create a deaf-friendly environment, thank you"). The test results and readings of the second sentence can be seen in Table 3 .

Table 3. Test result of the second sentence

\begin{tabular}{|c|c|c|c|c|c|c|c|}
\hline \multirow{2}{*}{ Sentence } & \multicolumn{2}{|c|}{$\begin{array}{c}\text { GyroSensor } \\
\text { Readings }\end{array}$} & \multicolumn{4}{|c|}{ Flex Sensor Readings } & \multirow[t]{2}{*}{ Note } \\
\hline & $\begin{array}{l}\text { Pitch } \\
\text { Value }\end{array}$ & $\begin{array}{l}\text { Roll } \\
\text { Value }\end{array}$ & Flex 1 & Flex 2 & Flex 3 & Flex 4 & \\
\hline Saya & $>75$ & $>90$ & $<1000$ & $<1000$ & $<1000$ & $<1000$ & Succeed \\
\hline Masyarakat & $>50$ & $>-100$ & $<1000$ & $<1000$ & $<1000$ & $<1000$ & Succeed \\
\hline Dengar & $>70$ & $>40$ & $<1000$ & $>1000$ & $>1000$ & $>1000$ & Succeed \\
\hline Berusaha & $>65$ & $>-50$ & $>1000$ & $>1000$ & $>1000$ & $>1000$ & Succeed \\
\hline Mewujudkan & $>65$ & $>-50$ & $>1000$ & $>1000$ & $>1000$ & $>1000$ & Succeed \\
\hline Lingkungan & $>65$ & $>-50$ & $>1000$ & $>1000$ & $>1000$ & $>1000$ & Succeed \\
\hline Ramah & $>5$ & $>-75$ & $<1000$ & $>1000$ & $>1000$ & $>1000$ & Succeed \\
\hline Tuli & $>25$ & $>-15$ & $<1000$ & $>1000$ & $>1000$ & $>1000$ & Succeed \\
\hline $\begin{array}{c}\text { Terima } \\
\text { Kasih }\end{array}$ & $>-5$ & $>-10$ & $<1000$ & $<1000$ & $<1000$ & $<1000$ & Succeed \\
\hline
\end{tabular}

\section{Results and Discussions}

After testing the finished system, both hardware and software, this device was able to be implemented directly at the Bali Deaf Community. A thorough training was carried out on the use of this device via online video conference, before the handover of this sign language interpreter device to the Bali Deaf Community. The training process was held online in June 2020 during the Covid-19 pandemic so that it could not be carried out in person but was carried out online. There were 15 participants who took part in the training, all of whom were Bali Deaf Community members. Figure 15 shows the training process activity mentioned. 


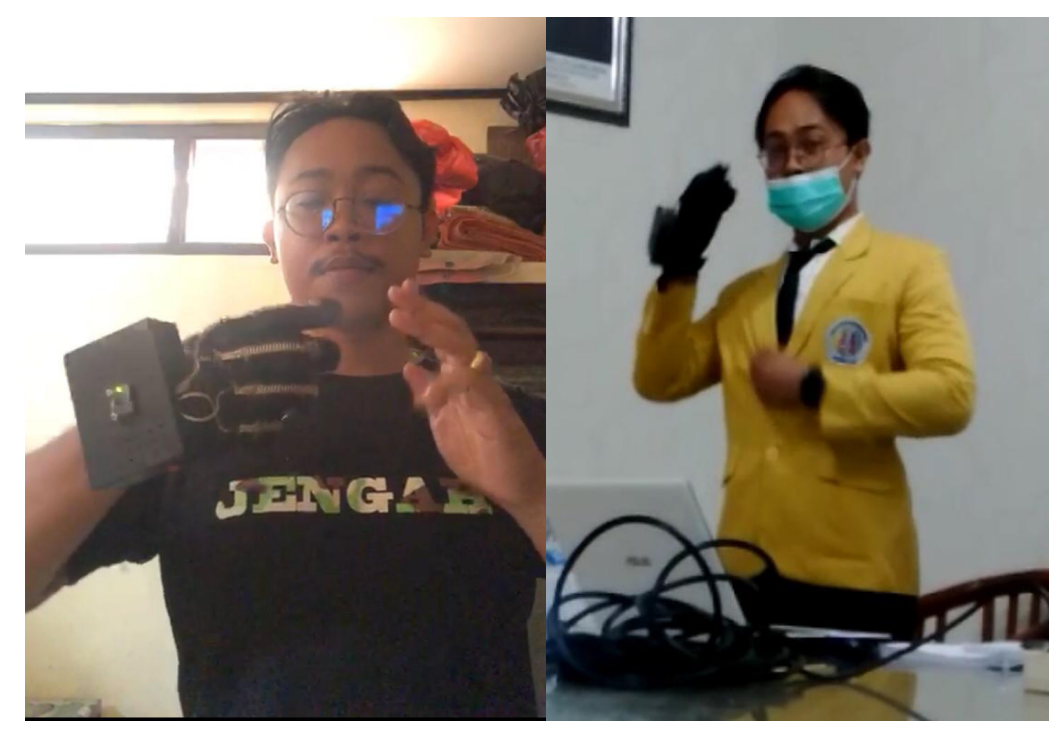

Fig. 15. Training sessions on how to use the sign language interpreter device

This training process was an initial stage of the community service activities carried out with the aim of providing information to the Bali Deaf Community that the system designed can help to convert sign language into sound using a microcontroller with several sentences as examples. The activity went well and smoothly, and 1 set (pair) of sign language interpreter device was handed over to the Bali Deaf Community manager at the end of July 2020.

For the next stage, the design will be refined by paying attention to the needs of users who will use this system as a means of communication by adding a few sentences that are often used to communicate in the Bali Deaf Community. The follow-up plan is to add features to improve the sign language interpreter device and to provide more unit of devices for the Bali Deaf Community.

\section{Conclusion}

From the results of the analysis of the Sign Language Interpreter Device with Sound Output, several conclusions can be drawn as follows:

1. To be able to implement the Sign Language Interpreter Device with Voice Output, a box measuring $14.5 \mathrm{~cm}$ long, $9.5 \mathrm{~cm}$ wide, and $5.5 \mathrm{~cm}$ high was required, made of plastic with a thickness of $3 \mathrm{~mm}$ to place all the components used. Agyro Sensor, 4 Flex Sensors, Arduino Uno controller module as an MP3 voice recorder module, a buzzer, and a 7.4 volt $850 \mathrm{mAh}$ battery are required. The performance of the Sign Language Interpreter Device with Voice Output was good, it worked well. 4 flex sensors were mounted on the glove 
along with a gyro sensor that can read the angle of movement of the hand between the xaxis (roll) or the y-axis (pitch). The flex sensor readings range from 998-1005 ADC (analog digital converter) when it is open and ranges from 1006-10018 ADC when it is closed.

2. The initial stage of the implementation of this device was to use several sentences according to the characteristics of the sign language gesture in the city of Denpasar which has its own language data rules with sentence patterns, namely Subject-Object-Verb or Subject-ObjectVerb-Subject and the next stage is to refine and complement several sentences, so that it can be used as a means of communication at the Bali Deaf Community.

3. A thorough training was carried out on the use of this device via online video conference, so that it can be used to help convert sign language into speech by the member of Bali Deaf Community. The follow-up plan is to refine the device by adding more features and to provide more units of sign language interpreter device needed by users who will use this system as a means of communicating in the Bali Deaf Community.

\section{Acknowledgements}

Praise our gratitude to God Almighty, for being able to complete the community service journal entitled "Design of Indonesian Sign Language Interpreter Device Based on ATMega328 Microcontroller for Bali Deaf Community Denpasar" on time. In the preparation of this community service journal, we received a lot of suggestions, criticism and encouragement from various parties, so that on this occasion we would like to express our deepest gratitude to:

1. Dr. Ir. Nyoman Sri Subawa, S.T.,S .Sos., M.M. as the Rector of Universitas Pendidikan Nasional Denpasar.

2. Ir. I Wayan Sutama, M.T., IPM as the Head of Research and Community Service Institution, Universitas Pendidikan Nasional Denpasar.

3. Ir. Agus Putu Abiyasa, B.Eng., Ph.D., IPM as the Dean of Faculty of Engineering andInformatics, Universitas Pendidikan Nasional Denpasar.

4. Ir. I Wayan Sugara Yasa, S.T.,M.T.,IPM as the Head of Electrical Engineering Laboratorium, Universitas Pendidikan Nasional Denpasar.

5. All lecturers in the Faculty of Engineering and Informatics, Universitas Pendidikan Nasional Denpasar.

6. Gede Ade Putra Wirawan as the Chairman of Bali Deaf Community. 


\section{References}

Ade, G., Wirawan, P., Harsemadi, I. G., \& Wiyati, R. K. (2019). Media Sosialisasi Pengenalan Bahasa Isyarat Indonesia Daerah Denpasar Berbasis Multimedia. Eksplora Informatika, $x(\mathrm{x}), 1-8$.

Effendi, J. (2018). Penjurubahasaan Dalam Bahasa Isyarat. Kongres Bahasa Indonesia, 1-16.

Fautin, A. 2017. Mengakses Modul Gyro Sensor, Retrieved from https://www.nyebarilmu.com/tutorial-arduino-mengakses-module-accelorometergyroscope-mpu6050/ [accessed on July 20, 2020].

Gumelar, G., Hafiar, H., \& Subekti, P. (2018). Bahasa Isyarat Indonesia Sebagai Budaya Tuli Melalui Pemaknaan Anggota Gerakan Untuk Kesejahteraan Tuna Rungu. Informasi, $48(1), 65$.

Kadir, A. (2013). Panduan Praktis Memplajari Aplikasi Mikrokontroler dan Pemogramannya Menggunakan Arduino. In Andi Komputindo (Vol. 8, Issue 1).

Kelasrobot. (2020). Pengaplikasian Lipo Battery 7,4 Volt pada Pengoperasian Mikrokontroler ATMega328. Bali: Kelasrobot.

$\begin{array}{lllll}\text { Sevianelia. } & \text { (2013). } & \text { Regulator } & \text { DC } & \text { Retrieved }\end{array}$ https://sevianelia.blogspot.com/2013/05/regulator-tegangan-dc.html [accessed on July 20, 2020].

Sulaiman, A. (2012). ARDUINO: Mikrokontroller bagi Pemula hingga Mahir. Available at: http://buletin.balaielektronika.com. [Accesed on Juli 26, 2020].

Wijaya, R. (2016). Flex Sensor. Retrieved from https://cobaarduino.blogspot.com/2016/06/menggunakan-sensor-flex.html [accessed on July 20, 2020]

Winoto, A. (2018). Mikrokontroler AVR ATmega8/32/16/8535 dan Pemrogramannya dengan Bahasa C pada WinAVR. Bandung: Informatika.

Yohanes, J. A., Arjawa, I. G. P. B. S., \& Punia, I. N. (2013). Bahasa Isyarat Indonesia Dalam Proses Interaksi Sosial Tuli dan "Masyarakat Dengar” di Kota Denpasar. OJS Unud, 115.

Zulfikar, M. (2018). Perancangan Sistem Penyiraman Tanaman Otomatis Berbasis Mikrokontroler ATMEGA328. Journal of Informatics and Computer Science Vol. 4 No. $1,4(1), 121$. 